\title{
ANTISEPTIC BANDAGING MATERIALS BASED ON SPHAGNUM
}

\author{
Kazan National Research Technological University, Kazan
}

I.Kh. Garayev, I.N. Musin, L.A. Zenitova

\begin{abstract}
The research focuses on preclinical studies of new antiseptic surgical bandaging material with a high absorption capacity based on plant raw material - sphagnum. In folk medicine, sphagnum is known as good antiseptic material. Partisans used it particularly actively in marshy forests of Belarus saving the wounded from death during the Great Patriotic War. Despite the fame in folk medicine, until now there is no industrial production of bandaging material on its basis. The possibility of practical solution of the issue of import substitution of bandaging materials with the help of this study confirms its significance. Besides, in literature, there is virtually no information on physical and chemical characteristics of sphagnum and reasons for its antiseptic properties. In this study, the composition of compounds giving antiseptic properties to sphagnum was investigated with the use of modern instrumental methods. The content of trace elements in the sphagnum composition was determined. A prototype of bandaging material was made, its ability to show antiseptic properties towards trace elements and fungi of Staphylococcus aureus, Actinomyces sp, Candida spp., E.Coli and Bacillus cereus was assessed. The conducted studies showed the fundamental possibility of creating new surgical bandaging materials on the basis of sphagnum with better performance characteristics in comparison with cotton-gauze bandaging materials.
\end{abstract}

Key words: antiseptics, bandaging material, trace elements, analysis.

Post-operative daily wound dressing causes unpleasant procedures related to irritation and injury of regenerating tissues resulting in bandage becoming a painful procedure for a patient. In this regard, it is necessary to search for bandaging materials having antiseptic properties for a long time and capable of absorbing wound effluents in large quantities. With the presence of such bandaging materials, there is no need for their frequent daily replacement.

The aim of this study is to check the possibility of creating antiseptic bandaging materials of high absorption capacity based on domestic raw materials. Sphagnum plant material was used as the main substance. We studied chemical compositions of sphagnum extracts using organic solvents, mass-spectrometric and IR-spectrometric methods. With that, the presence of various classes of compounds having antiseptic properties was found. Bandaging materials were made and tested for antiseptic activity towards various microorganisms. In addition, it was found that with long (over 10 years) storage the bandaging material does not lose its antiseptic properties.

Test samples are made by needle punching method with the punch frequency of 100-120 punctures per $1 \mathrm{~cm}^{2}$ in the form of three-layer cloth, the upper and lower layers of which consist of synthetic fibre, and the middle layer contains sphagnum dried and crushed to sizes of 50-150 $\mu \mathrm{m}$. The method of determining the sensitivity of microorganisms to antimicrobial compounds by the degree of their growth delay was used as a method for assessing antiseptic properties of experimental bandaging materials. The relative content of trace elements in sphagnum was determined by spectral method. In this respect, 23 trace elements were found in sphagnum, including phosphorus, silicium, aluminium, which stimulate growth and development of bone, connective and epithelium tissues, as well as facilitate recovery and regeneration processes.

\section{Materials and methods}

In order to find out the presence of organic substances giving antiseptic activity to sphagnum, it was extracted with toluene $\left(\mathrm{C}_{6} \mathrm{H}_{5}-\mathrm{CH}_{3}\right)$, carbon tetrachloride $\left(\mathrm{CCl}_{4}\right)$, water $\left(\mathrm{H}_{2} \mathrm{O}\right)$, acetone $\left(\mathrm{C}_{3} \mathrm{H}_{6} \mathrm{O}\right)$, and ethyl alcohol $\left(\mathrm{C}_{2} \mathrm{H}_{6} \mathrm{O}\right)$, and studies of the composition of these extracts were carried out. Extraction was carried out on the Soxhlet extractor at a temperature of $80-100^{\circ} \mathrm{C}$ for 3 hours. The ratio of sphagnum to solvents amounted to $1: 20 \mathrm{~g} / \mathrm{g}$. The resulting extract was filtered through a paper filter and used for testing.

The identification of substances extracted by the above solvents was carried out using mass spectroscopy in combination with gas ion chromatography on the MAESTRO GH 7820 chromatograph $[1,2]$. IR-spectrums were fixed on the JASCO FT/IR-6800 IR-Fourier spectrometer [3].

The sphagnum extract was obtained on the Soxhlet extractor. The ratio of sphagnum : solvent $=1: 20 \mathrm{~g} / \mathrm{g}$. The extraction was conducted while boiling of solvents for 3 hours. The solution was filtered though a paper filter and studied with mass spectroscopy and IR-spectroscopy for the presence of organic substances in the studied sphagnum extracts.

Then, studies on the antimicrobial effect of pure sphagnum and experimental bandaging material were carried out. For this purpose, we used methods based on the ability of antibiotics to diffuse in the microbial environment and to delay growth or even kill microorganisms in the 
antiseptic diffusion zone [4]. The microorganisms of Staphylococcus aureus, Actinomyces sp, Candida spp., E.Coli, and Bacillus cereus were used as test objects.

The studies were carried out on samples made by needle punching method, they consist of three layers: the upper and lower layer made of synthetic fibre, the middle layer made of shredded sphagnum 4-5 $\mathrm{mm}$ thick [5].

To determine the effect of sphagnum on the selected test object, the following methods were used: streaking method, disk diffusion test, and volume displacement method. Data on growth suppression in the sphagnum presence were determined in two days at a temperature of $37^{\circ} \mathrm{C}$.

The content of trace elements in sphagnum was identified through dividing the stems into three sections, as shown in Figure 1.

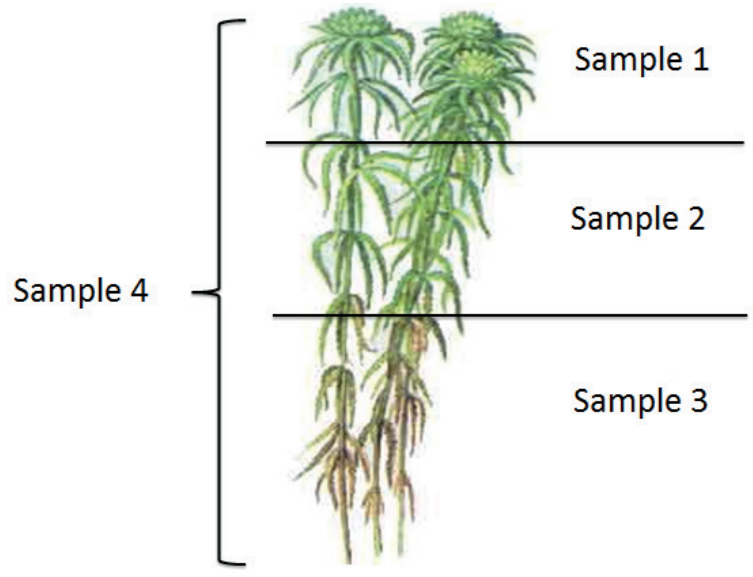

Figure 1. Division of the sphagnum stem for the studies on trace elements.
The presence of trace elements in sphagnum and their relative content were determined on the SPM-35 X-ray multichannel spectrophotometer.

For spectral studies, samples in the amount of $10 \mathrm{~g}$ were gradually heated for 30 minutes to a temperature of $1100^{\circ} \mathrm{C}$ and calcinated at this temperature for 30 minutes in a muffle furnace. The resulting ash was examined for the presence of trace elements.

\section{Results and discussion}

The fine interpretation of mass spectrograms of sphagnum extracts in toluene, carbon tetrachloride, ethyl alcohol, and water showed the presence of such substances as ethyl benzene, benzyl carbinol, acetophenone, phenylmethanol, benzene, phenol, acetic acid, styrene, etc. in tangible quantities. These substances contain aromatic nuclei or alcohol hydroxyl in the molecular structure, which give sphagnum antiseptic properties (Table 1). We did not consider in medical practice the presence of small amounts of hydrocarbons not being antiseptics.

It can be seen that sphagnum extracts contain compounds with aromatic rings being good antiseptics in medical practice.

For additional clarification of the chemical structure of macromolecular objects of sphagnum extracts, their IR-spectroscopy [3] was carried out on the FT- 801 spectrometer. The frequency interpretation is presented in Table 2.

Results of mass spectroscopy of sphagnum extracts in solvents

\begin{tabular}{|c|c|c|c|c|c|c|}
\hline \multirow{2}{*}{ Frequency } & \multicolumn{3}{|c}{ Content of substances in solvents, \% } & Component \\
\hline & $\mathrm{C}_{6} \mathrm{H}_{5} \mathrm{CH}_{3}$ & $\mathrm{CI}_{4}$ & $\mathrm{H}_{2} \mathrm{O}$ & $\mathrm{C}_{2} \mathrm{H}_{5} \mathrm{OH}$ & Ethyl benzene: $\mathrm{C}_{8} \mathrm{H}_{10}$ \\
\hline 8.593 & 6.06 & - & - & - & Benzene, (1-methylbutyl): $\mathrm{C}_{11} \mathrm{H}_{16}$ \\
\hline 13.282 & 0.30 & - & - & - & Acetophenone: $\mathrm{C}_{8} \mathrm{H}_{8} \mathrm{O}$ \\
\hline 617.904 & 0.46 & - & - & - & Phenylmethanol: $\mathrm{C}_{8} \mathrm{H}_{10} \mathrm{O}$ \\
\hline 18.392 & 5.32 & - & - & - & Ethyl benzene: $\mathrm{C}_{8} \mathrm{H}_{10}$ \\
\hline 9.708 & - & 0.29 & - & - & Phenylmethanol: $\mathrm{C}_{8} \mathrm{H}_{10} \mathrm{O}$ \\
\hline 19.616 & - & 0.26 & - & - & Phenol: $\mathrm{C}_{6} \mathrm{H}_{6} \mathrm{O}$ \\
\hline 2.001 & - & - & 0.03 & - & Glycolaldehyde dimer: $\mathrm{C}_{4} \mathrm{H}_{8} \mathrm{O}_{4}$ \\
\hline 2.208 & - & - & 0.02 & - & Acetic acid: $\mathrm{C}_{2} \mathrm{H}_{4} \mathrm{O}_{2}$ \\
\hline 2.302 & - & - & 0.06 & - & Acetol: $\mathrm{C}_{3} \mathrm{H}_{6} \mathrm{O}_{2}$ \\
\hline 2.843 & - & - & 0.02 & - & 1-propanol: $\mathrm{C}_{3} \mathrm{H}_{8} \mathrm{O}_{8}$ \\
\hline 1.941 & - & - & - & 7.49 & Styrene: $\mathrm{C}_{8} \mathrm{H}_{8}$ \\
\hline 10.126 & - & - & - & 7.04 & \\
\hline
\end{tabular}


Frequencies of IR-spectrum of sphagnum extract in solvents

\begin{tabular}{|c|c|}
\hline $\begin{array}{l}\text { Frequency } v, \\
\mathrm{~cm}^{-1}\end{array}$ & Compound classes in toluene \\
\hline 1740.94 & $\begin{array}{l}\text { Limit aliphatic }-\mathrm{CH}_{2}-\mathrm{CHO} \text {, cyclopentanone, alpha-halogen acids } \mathrm{CH}-\mathrm{COOH} \text {, carboxylic } \\
\text { acid anhydrides }-\mathrm{CO}-\mathrm{O}-\mathrm{CO}-\mathrm{v}_{\mathrm{c}=\mathrm{o}^{\prime}}\end{array}$ \\
\hline 1581.26 & Polyenes, primary amines $\mathrm{NH}_{2}$, pyridines and quinolines, pyrimidines and purines \\
\hline 1516.20 & Pyrimidines and purines, thiophenes \\
\hline 1463.65 & Nitrosamines $\mathrm{R}_{2} \mathrm{~N}-\mathrm{N}=\mathrm{O}$, boron compounds $\mathrm{BCH}_{3} \mathrm{~B}-\mathrm{Ar}$, \\
\hline 1160.27 & Propionates, higher esters, phosphoric acid esters $(\mathrm{RO})^{3} \mathrm{P}^{+}+\mathrm{O}^{-}$ \\
\hline 1106.86 & $\begin{array}{l}\text { Tertiary alcohols, aromatic acid esters, thiocarbonyl compound derivatives, benzene } \\
\text { compounds }\end{array}$ \\
\hline 1023.24 & Aromatic and vinylic $=\mathrm{C}-\mathrm{O}-\mathrm{C}-$, aliphatic amines, sulfur-containing functional groups \\
\hline \multirow[t]{2}{*}{722.78} & Alkanes, sulfur-containing functional groups \\
\hline & Compound classes in $\mathrm{CCl}_{4}$ \\
\hline 3306.80 & $\begin{array}{l}\text { Primary amines } \mathrm{R}-\mathrm{NH}_{2} \text {, secondary amines } \mathrm{R}_{2} \mathrm{~N}-\mathrm{H} \text {, amine salts } \mathrm{NH}_{4}^{+} \text {, boron compounds } \\
\mathrm{BOH} \text { B-H-B }\end{array}$ \\
\hline 2922.63 & Sulfur-containing functional groups R-SO-OH \\
\hline 2643.25 & Boron compounds, boranes $\mathrm{R}_{-} \mathrm{BH}_{2}$ \\
\hline 1740.94 & $\begin{array}{l}\text { Limit aliphatic }-\mathrm{CH}_{2}-\mathrm{CHO} \text {, cyclopentanone, alpha-halogen acids } \mathrm{CH}-\mathrm{COOH} \text {, carboxylic } \\
\text { acid anhydrides }-\mathrm{CO}-\mathrm{O}-\mathrm{CO}-\mathrm{v}_{c=0} \text {, }\end{array}$ \\
\hline 1581.26 & Polyenes, primary amines $\mathrm{NH}_{2}$, pyridines and quinolines, pyrimidines and purines \\
\hline 1516.20 & Pyrimidines and purines, thiophenes \\
\hline 1463.65 & Nitrosamines $\mathrm{R}_{2} \mathrm{~N}-\mathrm{N}=\mathrm{O}$, boron compounds $\mathrm{BCH}_{3} \mathrm{~B}-\mathrm{Ar}$, \\
\hline 1160.27 & Propionates, higher esters, phosphoric acid esters $(\mathrm{RO})^{3} \mathrm{P}^{+}+\mathrm{O}^{-}$ \\
\hline 1106.86 & $\begin{array}{l}\text { Tertiary alcohols, aromatic acid esters, organic compound halogen derivatives, } \\
\text { thiocarbonyl compound derivatives, benzene compounds, organophosphorous } \\
\text { compounds }\end{array}$ \\
\hline 1023.24 & Aromatic and vinylic $=\mathrm{C}-\mathrm{O}-\mathrm{C}-$, aliphatic amines, sulfur-containing functional groups \\
\hline 722.78 & Alkanes, sulfur-containing functional groups \\
\hline
\end{tabular}

The obtained data indicated that sphagnum contains in its composition a wide range of various compound classes showing antiseptic properties towards various groups of microorganisms. These are organochlorine and aromatic compounds, organophosphorous, primary and secondary aminocompounds, various alcohols. Data of IRspectrums of sphagnum extracts give a wider range of qualitative composition of substances compared to mass spectroscopy. The results of studies show the possibility of using sphagnum as an antiseptic component of bandaging materials.

Using sphagnum finely crushed to the sizes of 50-150 $\mu \mathrm{m}$, we made test samples of bandaging material and tested for antiseptic activity towards various microorganisms. The effect of test bandaging materials on various microorganisms was examined through different methods: streaking method, disk diffusion test, and volume displacement method [4]. The results of characteristics of bandaging material test samples are presented in Table 3.

The made material is a composite of synthetic fibre for forming the shape and of sphagnum as the main antiseptic component with high absorption capacity (Table 3, exp. 1, 2). With the increase in the content of sphagnum, its absorption capacity naturally increases (exp. 3-8). The made bandaging material was further tested for antiseptic activity, the results are presented in Table 4. 
Composition and physical and chemical characteristics of samples

\begin{tabular}{|c|c|c|c|c|c|}
\hline $\begin{array}{c}\text { No. of } \\
\text { experiments }\end{array}$ & \multicolumn{2}{|c|}{$\begin{array}{c}\text { Composition, \% of mass } \\
\text { synthetic fibre }\end{array}$} & $\begin{array}{c}\text { Water absorbing } \\
\text { sphagnum }\end{array}$ & $\begin{array}{c}\text { Density, g/ } \\
\text { cm3 }\end{array}$ & Ash content, \% \\
\hline 1 & - & 100 & $16-18$ & 1400 & 3.14 \\
\hline 2 & 100 & - & $3-4$ & 1800 & 4.1 \\
\hline 3 & 35 & 65 & 17.1 & 1800 & - \\
\hline 4 & 45 & 55 & 14.5 & 1840 & - \\
\hline 5 & 50 & 50 & 14.0 & 1810 & - \\
\hline 6 & 70 & 30 & 11.0 & 1740 & - \\
\hline 7 & 85 & 15 & 5.2 & 1700 & - \\
\hline
\end{tabular}

Table 4

The assessment of antiseptic activity of bandaging material samples towards various microorganisms

\begin{tabular}{|c|c|c|c|c|c|c|c|c|c|c|c|}
\hline \multirow{3}{*}{$\begin{array}{l}\text { No. of } \\
\text { experi- } \\
\text { ments }\end{array}$} & \multicolumn{2}{|c|}{$\begin{array}{c}\text { Composition } \\
\text { of samples, } \% \\
\text { of mass }\end{array}$} & \multicolumn{9}{|c|}{ Microorganism growth suppression, $\mathrm{mm}$} \\
\hline & \multirow[b]{2}{*}{$\begin{array}{l}\text { syn- } \\
\text { thetic } \\
\text { fibre }\end{array}$} & \multirow[b]{2}{*}{$\begin{array}{l}\text { sphag- } \\
\text { num }\end{array}$} & \multicolumn{3}{|c|}{ Staphyiococcus aureus } & \multicolumn{3}{|c|}{ Candida spp. } & \multicolumn{3}{|c|}{ Astinomyces sp. } \\
\hline & & & $\begin{array}{l}\text { streaking } \\
\text { method }\end{array}$ & $\begin{array}{l}\text { disk dif- } \\
\text { fusion } \\
\text { test }\end{array}$ & $\begin{array}{l}\text { volume } \\
\text { displace- } \\
\text { ment } \\
\text { method }\end{array}$ & $\begin{array}{l}\text { streaking } \\
\text { method }\end{array}$ & $\begin{array}{c}\text { disk } \\
\text { diffusion } \\
\text { test }\end{array}$ & $\begin{array}{l}\text { volume } \\
\text { displace- } \\
\text { ment } \\
\text { method }\end{array}$ & $\begin{array}{l}\text { streaking } \\
\text { method }\end{array}$ & $\begin{array}{c}\text { disk } \\
\text { diffusion } \\
\text { test }\end{array}$ & $\begin{array}{c}\text { volume } \\
\text { displace- } \\
\text { ment } \\
\text { method }\end{array}$ \\
\hline 1 & 35 & 65 & 45.0 & 63.9 & 16.7 & 13.1 & 31.1 & 14.6 & 10.4 & 83.1 & 86.6 \\
\hline 2 & 45 & 55 & 45.0 & 58.9 & 13.7 & 10.8 & 27.5 & 14.1 & 9.8 & 82.8 & 85.5 \\
\hline 3 & 50 & 50 & 45.9 & 56.7 & 15.2 & 9.5 & 25.5 & 13.5 & 9.4 & 80.1 & 85.1 \\
\hline 4 & 70 & 30 & 43.2 & 46.8 & 6.2 & 4.7 & 18 & 12.7 & 4.7 & 76.1 & 83.1 \\
\hline 5 & 85 & 15 & 43.2 & 38.7 & 1.5 & 0.7 & 11.1 & 12.7 & 5.7 & 72.9 & 81.5 \\
\hline 6 & 90 & 10 & 41.4 & 36.0 & 0.9 & 0.3 & 9.0 & 12.6 & 5.4 & 72.0 & 81.0 \\
\hline
\end{tabular}

With data presented in Table 4, it was revealed that through all testing methods sphagnum shows its antiseptic activity. Furthermore, the streaking method and disk diffusion test were more effective against strains of Staphylococcus aureus and Astinomyces sp. Growth suppression of Staphylococcus aureus cultures was 45, 63.9, and $86.6 \mathrm{~mm}$ respectively. The assessment of sample antiseptic activity towards fungi of the Candida spp. genus shows that the activity decreases by 2-3 times.

It was interesting to study the ability of antiseptic action of the made bandaging material in the process of long-term storage and under temperature. The test results are presented in Table 5. Antiseptic activity was tested towards E.Coli and Bacillus cereus microorganisms.

The assessment of antiseptic activity of long-storage samples towards E. Coli and Bacillus cereus

\begin{tabular}{|c|c|c|}
\hline \multirow{2}{*}{ Object under study } & \multicolumn{2}{|c|}{ Microorganism growth suppression, mm } \\
\hline Sphagnum (10-year-old) & E.Coli & Bacillus cereus \\
\hline Bandaging material & 13 & 10 \\
\hline Fresh sphagnum & 15 & 14 \\
\hline Dried sphagnum * & 15 & 15 \\
\hline
\end{tabular}

* drying was made at a temperature of $100-110^{\circ} \mathrm{C}$ for 3 hours. 
According to the results of studies, it was revealed that the sensitivity of sphagnum over time (more than 10 years) towards the E.Coli strain does not weaken. Sphagnum is active towards this strain through the non-woven material as well as fresh moss. As for Bacillus cereus bacteria, samples after 10-year storage show slightly less antiseptic activity towards this strain. Sphagnum drying is likely to lead to the removal of some lowboiling and more volatile compounds and, as a consequence, to the decrease in antiseptic activity of the bandaging material almost twice (Table 5).

The assessment of presence of trace elements in sphagnum is given in Table 6 .

Table 6

Results of sphagnum X-ray spectral analysis method (according to Figure 1)

\begin{tabular}{|c|c|c|c|c|}
\hline \multirow{2}{*}{ Metal samples } & \multicolumn{3}{|c|}{ Relative metal content, $\%$} & whole stem \\
\hline $\mathrm{Mg}$ & upper part & middle part & lower part & 5.90 \\
\hline $\mathrm{Al}$ & 5.84 & 5.80 & 5.70 & 3.60 \\
\hline $\mathrm{Si}$ & 3.50 & 3.45 & 3.6 & 19.0 \\
\hline $\mathrm{P}$ & 29.99 & 18.23 & 5.28 & 4.50 \\
\hline $\mathrm{S}$ & 2.30 & 3.07 & 4.19 & 6.40 \\
\hline $\mathrm{Cl}$ & 2.11 & 3.07 & 2.59 & 3.30 \\
\hline $\mathrm{K}$ & 0.55 & 3.36 & 68.34 & 30.0 \\
\hline $\mathrm{Ca}$ & 13.29 & 40.13 & 10.04 & 14.0 \\
\hline $\mathrm{Ti}$ & 15.11 & 17.86 & 0.16 & 0.50 \\
\hline $\mathrm{V}$ & 0.91 & 0.47 & 0.007 & - \\
\hline $\mathrm{Cr}$ & 0.02 & 0.009 & 0.005 & 0.04 \\
\hline $\mathrm{Mn}$ & 0.04 & 0.02 & 1.51 & 2.30 \\
\hline $\mathrm{Fe}$ & 1.98 & 1.86 & 3.49 & 21.0 \\
\hline $\mathrm{Ni}$ & 22.94 & 10.71 & 0.02 & 0.04 \\
\hline $\mathrm{Cu}$ & 0.05 & 0.03 & 0.07 & 0.07 \\
\hline $\mathrm{Gn}$ & 0.08 & 0.07 & 0.50 & 0.60 \\
\hline $\mathrm{Se}$ & 0.72 & 0.58 & - & - \\
\hline $\mathrm{Br}$ & 0.002 & - & 0.001 & - \\
\hline $\mathrm{Rb}$ & - & - & 0.02 & - \\
\hline $\mathrm{Sr}$ & 0.03 & 0.03 & 0.38 & 0.1 \\
\hline $\mathrm{Pa}$ & 0.07 & 0.16 & 0.09 & 0.2 \\
\hline & 0.15 & 0.12 & 0.05 & 0.09 \\
\hline
\end{tabular}

According to the data obtained, it has been found that sphagnum contains a large number of trace elements that contribute to wound healing. Such elements include phosphorus, silicium, aluminum, etc.

\section{Conclusions:}

1. Studies have shown that sphagnum contains a sufficient amount of substances potentially capable of antiseptic action on various conditionally pathogenic microorganisms.

2. The possibility of manufacturing new surgical bandaging materials with antiseptic properties and with high absorption capacity on domestic raw materials is shown.
3. It was found out that sphagnum contains a large number of trace elements, among which there are such elements as phosphorus, silicium, aluminum that contribute to the acceleration of regeneration of fresh tissues in wounds.

Conflict of interest. The authors declare that there is no conflict of interest.

\section{References:}

1. Klyuev N.A., Brodsky E.S. Modern methods of mass spectrometric analysis of organic compounds. Russian Chemical Journal. 2002; 46(4): 57-63.

2. Averko-Antonovich I.Yu., Bikmullin R.T. Methods of studying the structure and properties of polymers. Kazan, 2002: 604. 
3. Vasiliev A.V., Grinenko E.V., Shchukin A.O. Infrared spectroscopy of organic and natural compounds. SPb., 2007: 54.

4. GOST R ISO 20776-1-2010. Clinical laboratory tests and diagnostic test systems in vitro. Study on sensitivity of infectious agents and assessment of functional characteristics of products for study of sensitivity to antimicrobial agents. Part 1. Reference method of laboratory research of activity of antimicrobial agents against fast-growing aerobic bacteria causing infectious diseases. Intr. 01. 03. 2012. M.: Standartinform, 2012: 23.

5. Mandreykina A.A., Garayev I.Kh., Musin I.N., Vdovina T.V. Development of a new antiseptic surgical bandaging material based on sphagnum. Bulletin of Technological University. 2017; 20(23): 107-110.

\section{Contacts}

Corresponding author: Garayev Ilgiz Khazievich, Doctor of Technical Sciences, Associate Professor, Head of the Laboratory of the Department of Medical Engineering, Kazan National Research Technological University, Kazan.
420015, Kazan, ul. K. Marxa, 68.

Tel.: (843) 2314336.

E-mail: office@kstu.ru

\section{Author information}

Musin Ildar Nailevich, Candidate of Technical Sciences, Head of the Department of Medical Engineering, Kazan National Research Technological University, Kazan. 420015, Kazan, ul. K. Marxa, 68.

Tel.: (843) 2314383.

E-mail: ildarmusin@mail.ru

Zenitova Lyubov Andreevna, Doctor of Technical Sciences, Professor of the Department of Synthetic Rubber Technologies, Kazan National Research Technological University, Kazan.

420015, Kazan, ul. K. Marxa, 72.

Tel.: (843) 2314214.

E-mail: iptsk@kstu.ru 